\title{
Esbozo biográfico de Jorge Isaacs
}

\author{
José Eduardo Rueda Enciso
}

\begin{abstract}
Aside from his fame as the author of the best-selling novel Maria, Jorge Isaacs was well-known in his time for his adventurous undertakings. However, for most people nowadays the name of this author only evokes memories of a romantic nineteenth-century writer who forms part of the obligatory cannon in school. This article, not only tracks the author's family origins and his literary career, but it also allows the reader to become acquainted with the numerous political, scientific and academic activities that Isaacs carried out almost until the end of his life, the liberal and progressive character of his ideas, and the love-hate relationship that because of his ideals he had with his native region and his countrymen.
\end{abstract}

\section{Presentación}

Jorge Enrique Isaacs Ferrer es quizás uno de los personajes más representativos del siglo XIX colombiano y del carácter multifacético que tuvieron muchos de ellos: hacendados, comerciantes, políticos, poetas, escritores, pedagogos, periodistas y publicistas, militares, diplomáticos, católicos, masones, etc., manteniendo siempre un estrecho contacto con el hombre, la historia y el paisaje. A estas actividades y posiciones llegaron, o las tuvieron que asumir, obligados por las circunstancias y el medio ambiente en que se desenvolvieron, por lo que en repetidas ocasiones enfrentaron o grandes éxitos o estruendosos fracasos que afectaron su vida pública y privada. Así, a partir del periplo vital de Isaacs es posible reconstruir algunos trozos del agitado siglo XIX: las guerras civiles, las permanentes disputas entre liberales y conservadores, las frecuentes transformaciones de los polémicos personajes decimonónicos, las rencillas y odios que de allí surgieron, el mundillo intelectual de Bogotá y Popayán, así como la sociedad y la economía, circunstancias todas ellas en las que se denota el enfrentamiento entre una sociedad en búsqueda de la modernidad y otra abiertamente tradicional. 


\section{Las quiebras paternas}

Jorge Enrique ${ }^{1}$ Isaacs Ferrer nació en Cali el 1 de abril de 1837. Su padre fue George Henry lsaacs Adofus, judío británico de origen sefardí, ${ }^{2}$ oriundo de Montego Bay, Jamaica, donde había recibido una educación ilustrada. Isaacs Adofus se desplazó, desde Jamaica a la Nueva Granada en octubre de 1821, con destino final el Chocó. ${ }^{3}$ Emprendió este viaje motivado por el Libertador Simón Bolívar ${ }^{4}$ y atraído por las minas de oro allí existentes, pues “tenía presentes en su memoria las leyendas fabulosas que contaban los contrabandistas que cargados de oro y platino llegaban a las costas de Jamaica procedentes del río Atrato en el Chocó, en el famoso Velero Obligado". 5

Desde un comienzo don George comenzó a empaparse de la difícil condición para manejar las minas:

Primero, para iniciar cualquier explotación, el propietario de la concesión debía pagar a un capataz otro impuesto por el derecho de la explotación. Segundo, la población de trabajadores mineros, que en su mayoría eran negros yorubas y yolofos que venían de África, era itinerante y cada vez que podían se fugaban llevándose un puñado de oro entre sus manos, buscando mejores oportunidades de trabajo [...]. Tercero, los colonos blancos, que en su mayoría venían de las provincias de Antioquia y del Gran Cauca, vendían a su vez los derechos de explotación in situ, alquilaban a precios escandalosos la escasa y anticuada herramienta y traficaban con la mano de obra esclava. Cuarto, el extranjero o nacional que poseyera un permiso oficial para la explotación en las minas debía pagar un servicio de

1 Algunos autores, como Fabio Martínez, afirman que el verdadero nombre era Jorge Ricardo. María Teresa Cristina Z., quizás una de las mayores conocedoras de la vida y milagros de Isaacs, afirma que era Jorge Enrique.

2 El expresidente Alfonso López Michelsen (1913) tiene un excelente escrito titulado "Ensayo sobre la influencia semítica en María”. Los judíos sefardistas son los de la península ibérica que tuvieron que migrar de allí hacia mediados del siglo XVI por no querer convertirse al cristianismo, en lo que se ha llamado la Diáspora Sefardí. Los judíos llegaron a Jamaica luego del Tratado de Utrech de 1713, mediante el cual Curazao y Jamaica pasaron a formar parte de Holanda e Inglaterra respectivamente.

3 El periplo de George Henry fue: de Montego Bay se desplazó en el velero Alcatraz hasta Santa Marta, por tierra llegó hasta Pueblo Viejo (actualmente Barranquilla) y allí embarcó en un champán, río Magdalena arriba, con destino a Honda, pasando por los arrasados (a consecuencia de la reciente guerra de independencia) poblados de Guaimaro, Piñon, Barranca Nueva, Monpox, Pradilla, San Pablo y Garrapata. De Honda, a caballo, siguió a Guaduas, Villeta y Facatativa, Fontibón y Santafé de Bogotá. Una vez obtenido un permiso por seis meses y una autorización firmada por el Libertador para explotar las minas de oro de Certegué, Nóvita y el Raposo, se dirigió a Fontibón, La Mesa, Anapoima, Purificación, Ibagué, Cartago y finalmente, una vez atravesado a lomo de carguero el cañón de Garrapatas, Nóvita en el Chocó.

4 El ingreso de migrantes a Nueva Granada fue autorizado por el Libertador Simón Bolívar en 1813, decisión que fue ratificada por la ley del 30 de julio de 1824 y por el tratado de amistad y comercio suscrito con los Países Bajos en 1825.

5 Martínez, Fabio, La Búsqueda del paraíso. Biografía de Jorge Isaacs, Bogotá, Editorial Planeta Colombiana, 2003, p. 16. 
seguridad especial porque corría el riesgo de que lo robaran o lo mataran para quedarse con la concesión. ${ }^{6}$

Pese a todas esas dificultades, se instaló en un rancho que le compró a un señor de apellido Arboleda, adquirió una cuadrilla de negros comandada por Juan Biáfara, comenzó las explotaciones y el oro que extraía lo vendía en la oficina del Real de Minas al precio que esta quisiera comprárselo. Una vez pagado el respectivo impuesto, tenía que repartir un buen número de morrocotas de oro entre los capataces para que vigilaran a los negros que huían con el metal y a los contrabandistas que frecuentemente atacaban el campamento. Durante tres años aguantó el duro trajín, pero entre 1825 y 1826, convencido de que podía obtener ganancias sin arriesgarse tanto, decidió establecerse como comerciante en Quibdó, donde logró acumular cierto capital gracias a que su almacén era el de mayor concurrencia pues, desde Cartagena, traía muy variada y rica mercancía. No se sabe si en Nóvita o en el mismo Quibdó, o en los viajes que hacía a Cartagena, adquirió el mal de la malaria.

En Quibdó George Henry Isaacs Adofus conoció a Manuela Ferrer Scarpetta, hija del militar catalán Carlos Ferrer (fusilado en la población de Majagual por su fidelidad al rey de Espańa) y de madre italiana, perteneciente a lo más granado de la sociedad caleña, con quien contrajo matrimonio una vez que se convirtió al cristianismo en 1828 y se nacionalizó en $1829 .{ }^{7}$ A los dos meses de haber contraído tuvo su primera quiebra debido a un incendio que acabo con sus bienes. Como tenía ahorrados algunos dineros y contaba con la dote recibida de su esposa de 3.663 pesos de plata decidió, a instancias de dońa Manuelita, trasladarse a Santiago de Cali en Valle del Cauca. ${ }^{8}$

La joven pareja Isaacs-Ferrer arribó a Cali a mediados de 1830 y se instaló en una casa del barrio El Peńón, ${ }^{9}$ entre el charco de El Burro y la colina de San Antonio. Gracias a los vínculos familiares de dońa Manuelita, don George consiguió el cargo de rematador de bienes del general Obando y al poco tiempo fue nombrado jefe del cantón de Villa de las Palmas, antiguo Llanogrande.

6 Martínez, Op Cit., pp. 46 y 47.

7 Tal pauta de matrimonio, un emigrante casado con una rica heredera, se había impuesto en la Nueva Granada desde bien temprano pero, durante el siglo XVIII, fue predominante dentro del grupo de nuevos funcionarios que llegaron con motivo de las reformas borbónicas y la creación del virreinato. A partir de tales uniones matrimoniales se conformaron círculos y redes que durante el periodo inmediatamente anterior y durante la independencia se convirtieron en grupos de poder.

8 De Quibdó se dirigió, junto con su esposa, por el río San Juan, hasta Buenaventura. De Buenaventura, por el río Sabaletas, llegaron hasta la desembocadura del río Dagua, atravesaron la región de La Víbora hasta Juntas, donde tomaron mulas y por el camino de la cordillera hasta el alto de las Tres Cruces para descolgarse hasta Cali.

9 Inicialmente le pagaron arriendo a don Lorenzo Umańa, pero en 1843, al hacer efectivos los dineros de la dote de su esposa, don George Henry la adquirió y esta pasó a ser la casa paterna de los Isaacs. 
Posteriormente, en 1837, fue nombrado gobernador de la Provincia de Buenaventura y en 1838 jefe político del cantón de Villa de Las Palmas, que por orden del cabildo se siguió llamando el cantón de Palmira. Desde su llegada al Valle del Cauca se interesó por el cultivo de la caña de azúcar, que trasformó la economía de la región, y la producción de miel y pan de azúcar. En fin, soñaba en convertirse en un rico terrateniente, con todo lo que ello llevaba implícito en aquella época: casa con trapiche, tierras, estancia, ganado, esclavos y demás enseres. En 1840 compró a don Mario Becerra los terrenos planos de la hacienda La Rita, ubicada en las afueras de Palmira, entre los ríos Nima y Amaine, a los que bautizó con el nombre de La Manuelita, como un homenaje a su esposa; en 1843 adquirió la casa de El Peñón, en Cali, donde vivió la mayor parte del tiempo. En su hacienda de Palmira tuvo cuadrilla de negros, inició el ambicionado cultivo de caña de azúcar y por primera vez en la región se produjo miel de purga y el pan de azúcar que abastecieron los mercados de Cali, Palmira, Buga y Popayán. Como funcionario público se comprometió en la construcción del camino a Buenaventura y en el de Cali-Palmira; construyó el matadero, la sede del cabildo y ayudó a trazar la cuadrícula urbana de Palmira.

Posteriormente, en 1855, apoyado por el presidente de la república y gran amigo suyo, don Manuel María Mallarino (1808-1872), don George Henry compró la hacienda de La Sierra ${ }^{10}$ que posteriormente Jorge Enrique inmortalizó con el nombre "El Paraíso". Sin embargo, a los tres años la tuvo que vender acosado por los acreedores que se querían quedar con ella. Tuvo una numerosa familia, trece hijos, de los cuales sobrevivieron nueve. Jorge Enrique fue el quinto, pero el segundo en sobrevivir, y pasó a ser el favorito de su padre. Conservador convencido, don George se vino abajo, económica y moralmente, con la ley del 7 de marzo de 1851 mediante la cual se abolió la esclavitud en territorio colombiano. Muy a su pesar, y luego de una corta guerra civil de dos meses, los grandes hacendados caucanos, entre los que se encontraba Isaacs Adofus, ${ }^{11}$ tuvieron que aceptar la orden de manumisión y otorgarle la libertad a sus esclavos, con lo que definitivamente cambiaron las relaciones laborales que se vivían en el campo colombiano. Pero, como en su mayoría eran conservadores, se opusieron a las medidas impuestas por los liberales en el poder, como por ejemplo la expulsión de los jesuitas. Todo esto significó la ruina para muchos terratenientes, incluido George Henry, quien para mitigar la quiebra comenzó a

10 La casa de la Sierra hacía parte de del fundo de Piedechinche, donde nació el general Eusebio Borrero y actualmente es la sede del Museo de la Caña. Perteneció a don Víctor Cabal, a don Manuel María Mallarino, a Federico Byrne y finalmente a Isaacs Adofus. En 1952 el gobierno nacional compró la hacienda El Paraíso y la declaró patrimonio nacional.

11 Algunos de los grandes hacendados caucanos fueron: Manuel María Mallarino, Manuel José Escobar, José Lloreda, Antonio Carvajal, Francisco Borrero, Víctor Cabal, Josefa Castro, Manuel María Buenaventura, José María Guerrero, Antonio Zamorano, Carlos Palau, Julián Vallecilla, Juan Antonio Caicedo y Petronila Herrera. 
frecuentar las pulperías de Santa Rosa y La Mano del Negro, donde se aficionó a los juegos de tresillo y al de dados, buscando quizás un golpe de suerte. Igualmente se aficionó a las aventuras y al aguardiente, para ahogar en él la pena. Al final de cuentas, don George dilapidó el resto de su fortuna, pues por prestarle atención al juego ${ }^{12}$ y al licor descuidó sus haciendas, circunstancia que marcó la vida de Jorge Enrique.

\section{Infancia y juventud}

Jorge Enrique Isaacs Ferrer pasó su niñez entre la casa de El Peñón y la hacienda Manuelita. No son muy claras las circunstancias por las cuales la familia Isaacs-Ferrer se desplazó a Popayán. Lo cierto es que allí aprendió Jorge Enrique sus primeras letras con doña Matilde Pombo O'Donnell, la madre de los caudillos caucanos Julio (1817-1862) y Sergio (1822-1888) Arboleda, de los que fue gran amigo pero también gran contradictor. Continuó sus primeros años de estudio en Popayán, en la escuela del maestro Manuel María Luna, que también fue profesor de los hermanos Arboleda y otras personalidades del Cauca de entonces, es decir desde muy niño conoció y quizás comenzó a sufrir a lo más rancio de la aristocracia caucana. En 1848, la familia Isaacs Ferrer retornó al Valle y Jorge fue enviado a estudiar a Bogotá, al Colegio del Espíritu Santo, ${ }^{13}$ que regentaba el notable pedagogo y dramaturgo Lorenzo María Lleras (18111868); posteriormente pasó al Colegio de San Buenaventura y posteriormente al de San Bartolomé. En estos colegios, especialmente en el primero, se educaba la nueva elite del país y en ellos el adolescente caucano Jorge Enrique Isaacs Ferrer se empapó de las ideas liberales. Sin terminar sus estudios regresó, entre 1852 y 1853 , a Cali y como la situación económica de la familia era ya difícil, no pudo viajar a Inglaterra para estudiar medicina. Se encontró con una ciudad convulsionada por la revuelta de los artesanos y de los esclavos. Estos últimos, protegidos por la ley de liberación de los esclavos de 1851, abandonaron las haciendas ganaderas y cańeras del Valle del Cauca, circunstancia que ayudó al derrumbe económico de don George Henry, pues de la noche a la mañana se quedó sin mano de obra.

En 1854, en plena adolescencia, Jorge Enrique se alistó como alférez para participar en la guerra contra la dictadura del general José María Melo (1800-

12 Según parece, "con frecuencia se acercó al juzgado a firmar ante el notario público una declaración donde se comprometía a pagar una multa de quinientos pesos si volvía a jugar en las pulperías o si jugaba por interpuesta persona”. Martínez, Op. Cit., pág. 72.

13 El Colegio del Espíritu Santo fue fundado en 1846 por Lorenzo María Lleras, quien lo regentó hasta 1853, tiempo suficiente para influenciar, moral y literariamente a toda una generación, la de los románticos pero esencialmente a los radicales, pues por el claustro pasaron muchos de sus más representativas figuras. 
1860). Fue abanderado de la columna Torres que dirigió el coronel Manuel Tejada y su primera batalla la adelantó contra las fuerzas de los artesanos, militares y liberales draconianos partidarios de Melo que se hallaban acantonadas en Palmira. Permaneció en campaña durante siete meses, tiempo en el que vio

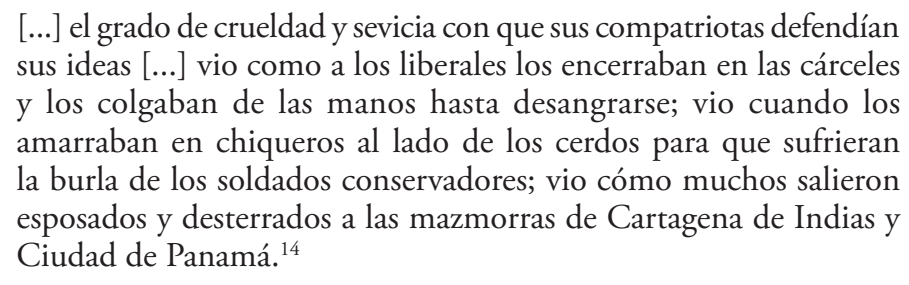

En 1856, a los 19 años, contrajo matrimonio con la bella caleña Felisa González Umaña, quien sólo contaba catorce años y con quien tuvo, pese a sus fugas y abandonos, nueve hijos, de los que sobrevivieron siete (tres mujeres y cuatro hombres). Desde el fin de la guerra, en diciembre de 1854, comenzó a trabajar, durante el año de 1855, como comerciante en Cali. Una vez que contrajo matrimonio se instaló en la hacienda La Rita, quizás por la emoción de los primeros años de matrimonio y la posibilidad de salvar el patrimonio familiar. A consecuencia de la pérdida de esta hacienda, a los tres ańos de adquirida, fue que la inmortalizó en María. Entonces era conservador, pero sentía cierta inclinación por las ideas liberales que había conocido durante su permanencia en Bogotá.

El 8 de mayo de 1860 el general Tomás Cipriano de Mosquera (1798-1878) se rebeló en el sur contra el gobierno de Mariano Ospina Rodríguez (18051885). Opuesto Isaacs a ese alzamiento, se vinculó a los ejércitos del gobierno institucional y participó en algunas batallas importantes, como las del Puente de Cali y Manizales. La mayor parte de los dos años que duró el conflicto lo pasó en tierras antioqueńas bajo las órdenes del general Braulio Henao, y en sus horas de descanso escribió una buena cantidad de poemas nostálgicos, evocativos del hogar y del Valle del Cauca. El más importante de ellos fue Río Moro, que además de ser un homenaje al cauce que discurre entre Sonsón y Victoria, en el camino de Antioquia al Magdalena en medio de una naturaleza salvaje y pintoresca, refleja el carácter aventurero de lsaacs, su amor a la naturaleza selvática, a la cacería, a las exploraciones lejanas y a la existencia libre y solitaria. En esa permanencia en tierras antioqueñas conoció al poeta Gregorio Gutiérrez González (1826-1872), quien en 1866, un año antes de aparecer María, publicó La memoria del cultivo del maiz en Antioquia. Al terminar la guerra civil, en 1861, con el triunfo de Mosquera, Isaacs retornó al Valle del Cauca a hacerse cargo, en contra de su voluntad, de los maltrechos negocios familiares, pues su padre había muerto del 
mal de muchos alcohólicos: la cirrosis. Según el testamento de George Henry, Jorge Enrique debía apersonarse de los intereses paternos. Se dedicó entonces al comercio y dejó de lado algunos estudios de botánica, anatomía y medicina que había iniciado por su cuenta. Para mitigar un tanto la frustración se dedicó a la literatura, escribió varios poemas y algunas obras dramáticas.

Dos años duró Isaacs tratando de sacar a flote las haciendas y demás intereses del legado paterno, con la ayuda jurídica del abogado y escritor Eustaquio Palacios, pero todo resultó infructuoso pues era inexperto e incrementó las ya altas hipotecas sin lograr una mejoría de los negocios familiares. A consecuencia de los pleitos familiares tuvo que viajar a Bogotá, a finales de 1863, a buscar abogados que lo salvaran de la quiebra. En la capital de la Unión entró en contacto con los abogados José María Vergara y Vergara (1831-1872) y Aníbal Galindo. Vergara y Vergara era, para ese entonces, el más importante animador y promotor de la actividad cultural en la capital y particularmente de los jóvenes escritores, especialmente desde la heterogénea y pluralista tertulia de El Mosaico, ${ }^{15}$ en la que, dejando de lado los odios y rencillas políticas, se reunían los más importantes intelectuales del momento, al calor de un tradicional chocolate santafereńo o de la degustación del agua de ajenjo, a leer poemas y ensayos literarios. Se estrenaban allí composiciones musicales y se departía sobre distintos temas de la inteligencia, unidos por el romanticismo reinante. ${ }^{16}$ Como complemento de la tertulia funcionaba una revista quincenal del mismo nombre.

Conoció Vergara y Vergara las inclinaciones poéticas de su joven cliente y lo invitó, en mayo de 1864, a presentar sus poemas en una sesión extraordinaria en la casa de José María Samper Agudelo (1828-1888), ante 14 escritores. ${ }^{17}$ Este evento resultó todo un éxito para el novel bardo, pues obtuvo el reconocimiento como poeta ya que, según El Mosaico, Isaacs era una "novedad literaria". La plenaria decidió publicar sus 30 composiciones ligeras, entre sentimentales y festivas, algunas con desalińos métricos, en las que además de evocar su terruño, en Río Moro por ejemplo, recordaba sus campañas militares en poemas como $\mathrm{La}$

15 La tertulia de El Mosaico es uno de los ejemplos clásicos de la sociabilidad cultural que se vivió durante la segunda mitad del siglo XIX colombiano. Fue fundada en 1858 por José María Vergara y Vergara y por Eugenio Díaz Castro (1803-1865). La primera época de funcionamiento de la tertulia va de 1858 a 1860; la segunda época va de 1864 a 1865, es decir cuando Isaacs entró en contacto con el director natural de El Mosaico; la tercera época va de 1871 a 1872 . Vergara y Vergara sería el fundador y primer director, en 1871, de la Academia Colombiana de La Lengua, la primera correspondiente de la Española. Junto a Vergara, los fundadores fueron: José Manuel Marroquín (primer secretario), Miguel Antonio Caro, Ezequiel Uricoechea, Rufino José Cuervo.

16 Los miembros de la tertulia se reunían en veladas que se llevaban a cabo en las casas de los contertulios, que por la heterogeneidad de sus integrantes se les denominó "mosaicos".

17 José María Samper, José Manuel Marroquín, Ezequiel Uricoechea, Ricardo Carrasquilla, Aníbal Galindo, Próspero Pereira Gamba, Diego Fallon, José María Quijano Otero, Rafael Samper, Teodoro Valenzuela, José María Vergara y Vergara, Ricardo Becerra, Salvador Camacho Roldán y Manuel Pombo. 
muerte del sargento, La vuelta del recluta y La reina del campamento. Según el acta de recomendación de publicación de las poesías de Isaacs, se dice que:

En una de las últimas noches del mes de Mayo, estábamos reunidos en casa de uno de nosotros y esperábamos oír leer las poesías de un joven cuyo nombre nos era, hasta entonces, apenas conocido.

Leída la primera composición, experimentámos dos sentimientos: de admiración el primero, admiración semejante a la que produce la vista de una de las magníficas auroras del Cauca.

De temor el segundo, al pensar que aquellas armonías, que tan dulces nos habían parecido, podían quizá desvanecerse, que la inspiración del poeta pudiera haber sido fugitiva.

Pero nuestra admiración creció, y la lectura de las otras composiciones disipó nuestro temor. Entusiasmados, al fin, ofrecimos al inspirado joven las sinceras simpatías de nuestros corazones expresadas en fervorosos elogios.

Digímosle cuanto podíamos darle; devolvémosle, ahora, impresas las poesías que entonces nos leyó manuscritas; dámosle también nuestros nombres, firmando, no una recomendación, que para tánto no nos creemos competentes, sino una carta de introducción para el público: a éste toca juzgar el mérito del libro que presentamos. ${ }^{18}$

Tal parece que los meses que Isaacs estuvo en Bogotá fueron de intensa actividad intelectual, pues además de asistir al Mosaico, también participó en algunas veladas en casa de Miguel Antonio Caro (1843-1909).

Pese a los esfuerzos que realizó por salvar el patrimonio familiar, Isaacs tuvo que vender la hacienda La Manuelita para responder a los compromisos establecidos con más de treinta acreedores. El afortunado comprador, pues la adquirió por las dos terceras partes de su valor, fue el letón Santiago Martín Eder (1830-1921) y fueron ellas la base de La Manuelita, uno de los más importantes ingenios del Valle del Cauca. Desde esa época, Jorge Enrique mostró gran atracción por los viajes, las exploraciones y sobre todo la observación del paisaje natural y cultural. Aunque dolorosa, la pérdida de la hacienda La Manuelita significó la ruptura con un medio social patriarcal y esclavista, totalmente conservador, y la vinculación al radicalismo, su redención como escritor, como político, como educador y como etnógrafo.

\section{María}

De regreso nuevamente al Valle del Cauca, y con grandes apremios económicos, Isaacs tuvo que aceptar, en noviembre de 1864, el cargo en el que lo quiso nombrar Tomás Cipriano de Mosquera: subinspector de los trabajos del 
camino de herradura entre Buenaventura y Cali, con residencia en el campamento La Víbora, en las selvas de Dagua. Esta obra pública se consideró de cardinal importancia para el país y sobre todo redentora para el Cauca, y en ella Isaacs tuvo que manejar entre trescientos y cuatrocientos obreros con los que se compenetró y aprendió a convivir como ellos. En efecto, allí vivió una experiencia equiparable a la del trabajo de campo de cualquier etnógrafo: habitó en un rancho de palma de chonta; comió una masa hecha con plátano hartón y guineo cocidos, llamado fufú, así como sustancioso sancocho de pescado nayo; en las noches y horas libres escuchó la cadenciosa música de los negros interpretada en tambores, carrasca y carangana o marimba; aspiró la cóngola o pipa de negros, durmió en hamaca, arrullado por los sonidos de la selva pero también tuvo que aguantar el zumbido y picaduras de zancudos, la amenaza de los animales salvajes y las serpientes. En ese ambiente comenzó a escribir los borradores de los primeros capítulos de su novela María. Isaacs, en carta autobiográfica, a su amigo Adriano Páez, recuerda así la estadía en La Víbora:

Hay una época de lucha titánica en mi vida: la de 1864 a 1865; viví como inspector del camino de Buenaventura, que se empezaba a construir entonces, en los desiertos vírgenes y malsanos de la costa del Pacífico. Vivía entonces como salvaje, a merced de las lluvias, rodeado siempre de una naturaleza hermosa, pero refractaria a toda civilización y armada de todos los reptiles venenosos y de todos los hálitos emponzońados de la selva. Los trescientos o cuatrocientos negros obreros que tenía bajo mis ordenes y con quienes habitaba como un compañero, tenían casi adoración por mí. Trabajé y luché hasta caer medio muerto por obra de la fatigante tarea y del mal clima. Después he hecho cuanto mis fuerzas han permitido, hasta el Congreso de 1878, a favor de la vía redentora para el Cauca; pero nada ha sido eso comparándolo con lo que hice y sufrí como inspector de los trabajos desde noviembre de 1864 hasta el mismo mes de $1865 .{ }^{19}$

Se trasladó luego a Cali, a la casa de El Peńón, con el fin de recuperarse del paludismo contraído en las selvas de Dagua y continuó la redacción de su opus magnun, cuya primera edición (ochocientos ejemplares) apareció en Bogotá, en mayo de 1867, en la imprenta de José Benito Gaitán y la revisión de Ricardo Carrasquilla. El libro desde un principio fue un verdadero éxito literario, mas no económico, pues en vida Isaacs sólo recibió 200 pesos por derechos de autor y 200 ejemplares, en 1889, para que los comercializara. La crítica no se cansó en resaltar la obra: es así como, el posterior ultramontano José Joaquín Ortiz (1814-1892), en su periódico La Caridad, lecturas del hogar escribió que: "El autor de María hace tres [años] que se presentó en Bogotá con un volumen de 
versos que fueron recibidos con raro entusiasmo; i hace pocos días que ha dado un nuevo volumen en prosa, conteniendo una novela bien elaborada, bien escrita, un ser triple, indefinible, es una Rebeca sajona viviendo en Sevilla” ${ }^{20}$

Dos años después, en 1869, apareció una segunda edición, esta vez revisada por Miguel Antonio Caro e impresa en la imprenta de Medardo Rivas ${ }^{21}$ (18251901). A lo largo de la historia de la literatura colombiana María ha sido uno de los libros más difundidos, tanto en Colombia como en el mundo entero, pues a lo largo de 138 años de haberse publicado por primera vez se han hecho múltiples ediciones, ${ }^{22}$ desde México a Argentina, aun cuando el analfabetismo de nuestros países alcanzaba por lo menos el $80 \%$ de la población.

Considerada como la obra cumbre del romanticismo latinoamericano, que es diferente al romanticismo europeo así tenga "elementos comunes como la idolatría por la naturaleza campesina, la idealización de la sociedad desconociendo los conflictos sociales, la presencia del amor como un imposible. Pero los argumentos para igualar ambos romanticismos son imprecisos [...]", ${ }^{23}$ pues no se encuentran las búsquedas estético-filosóficas de Goethe, ni el retorno al mundo cultural de la Grecia clásica, ni a la sensibilidad místico-religiosa o las feroces diatribas

20 La Caridad, No 41. Bogotá: julio 5 de 1867. pág. 649. Con anterioridad, en 1864, cuando fue lanzado el volumen con las poesías de Isaacs, Ortiz había escrito en el mismo periódico un elogioso comentario en el que dijo: "Al aparecer en el firmamento un nuevo astro, que viene después de una noche de larga y desecha tempestad á fulgurar retocado de oro el cenit de su carrera, es muy justo saludarlo con voz reconocida; y al presentarse un nuevo cantor, antes desconocido, que con suave lira asciende al templo de la gloria [...] El tono del seńor Isaacs es noble, alto, apasionado y original. Es un poeta que canta á solas, sin pensar que haya quien pueda escucharle, de donde derivan sus poesías el merito sobresaliente de la espontaneidad”. La Caridad, No 5, Bogotá, 1864.

21 La tercera edición (1878) contó con el mismo equipo editorial: Caro y Rivas. La edición definitiva de María data de 1922 cuando sus herederos la publicaron en la Imprenta de Camacho Roldán y Tamayo, basados en un ejemplar de la primera edición corregida por el mismo Isaacs y en un cuadernillo que contenía algunas instrucciones preparadas por él para una reedición que nunca pudo realizar. (Gustavo Mejía. Criterios de la Edición de Ayacucho, 1978).

22 Según el fichero de la Biblioteca Nacional, existen 27 ediciones impresas en Castellano de María, entre 1867 y 2004, e innumerables reimpresiones. En el 2001 se hizo una en disco compacto. Entre 1867 y 1889 se publicaron en el exterior 25 ediciones de María, de las cuales 14 se hicieron en México, en la Imprenta Aguilar e Hijos, así como traducciones al inglés, francés, holandés y portugués. Hay dos excelentes ediciones críticas: la de Donald McGrady para la Editorial Labor de Barcelona en 1970 y la de Mario Carvajal para la Biblioteca de la Universidad del Valle en 1967, que es quizás la mejor. La obra, además, cuenta con dos versiones para cine, dos para televisión y una para radio. Tanto en la primera versión de televisión como en la de radio, María fue interpretada por María Eugenia Dávila y las adaptaciones corrieron a cargo de Bernardo Romero Lozano, la de radio, y Bernardo Romero Pereiro, la de televisión. La última adaptación para televisión fue escrita por Gabriel García Márquez y la dirigió Lisandro Duque. La primera versión para cine data de 1922 y marcó toda una época en la historia del cine colombiano. Fue filmada en El Paraíso, bajo la codirección de los españoles Alfredo del Diestro y Máximo Calvo, con la producción del ex franciscano Francisco Posada. Sobre la novela escribieron contemporáneos de Isaacs como Luciano Rivera y Garrido, Eustaquio Palacios, Medardo Rivas, José Manuel Marroquín y Baldomero Sanín Cano, entre otros. En España, José María de Pereda; en Argentina, Miguel Cane; en México, Manuel Gutiérrez Nájera.

23 Prólogo a la Edición de Panamericana Editorial Ltda., 1993, p. 3. La primera edición de esta casa editorial se cumplió en 1993, para el año 2004 se habían adelantado 10 reediciones. 
histórico-revolucionarias de Victor Hugo. Retomando a Pedro Henríquez Ureña, diremos que:

[...]nuestro romanticismo lo caracterizan elementos específicamente nacionales: es el movimiento estético paralelo a las revoluciones de Independencia (1810-1830) y que canta sus triunfos. El escritor romántico latinoamericano - a diferencia radical del europeoparticipa activamente en asuntos políticos de su país [...] Además nuestro romanticismo es idealista —nada escéptico o individualista como el europeo-y busca reflejar una Utopía de cambio permanente $[\ldots] .^{24}$

Si tomamos como ciertas las aseveraciones de Henríquez Ureña, el romanticismo de Isaacs está marcado por una visión cristiana y sentimental, totalmente lírico, ambivalente y contradictorio, donde se presenta un amor metafísico rodeado de una atmósfera fúnebre, pero que expresa más una estética ilustrada que la desmesura de la pasión, subrayando que en ocasiones abusó de "ciertos artificios elementales, propios de toda novela romántica, como son las escenas de llanto, con las cuales el autor pretende poner un marco adecuado al intenso dolor de los amantes, y solo consigue dejarnos la sensación de algo artificial, desprovisto de todo calor humano". ${ }^{25}$ De todas formas, María es, sin lugar a dudas, la primera novela colombiana que rompió sus límites provincianos y se incrustó en la literatura universal.

En María se describe y evoca, de manera magistral, el imponente paisaje y la naturaleza del Valle del Cauca, elementos que son un personaje más de la obra y que pintó Isaacs unas veces serenos o idílicos, otras desapacibles, sombríos o tempestuosos, a medida que avanzó en la narración del fatal idilio entre María y Efraín o de acuerdo con los estados de ánimo de los protagonistas y demás personajes de la novela. Es así como:

[...] entre los aspectos más notables de la prosa de Isaacs sobresalen el ritmo cadencioso de su oración y su riqueza cromática en el tratamiento del paisaje. El novelista está atento a los matices y tonalidades de la luz, en las diferentes horas del día, que subrayan la melancolía en los atardeceres en los momentos de ensoñación, que entristecen las noches, o vuelven tenebroso o lúgubre el valle. ${ }^{26}$

24 Prólogo a la Edición de Panamericana Editorial Ltda., 1993, p. 4.

25 López Michelsen, Alfonso, “Ensayo sobre la influencia semítica en María”, en: Ensayistas colombianos del siglo XX (Compilación y prologo de Jorge Eliécer Ruiz). Bogotá: Biblioteca Básica Colombiana, Colcultura, 1976, pág. 205.

26 Cristina, María Teresa. Introducción a María. Una mirada fotográfica al Valle del Cauca, Cali: Panamericana, 2002. 
Pero, Isaacs describió también, sin proponérselo, las diferentes costumbres locales ya que:

[...] no pretendió elaborar estudios sicológicos, reconstruir ambientes históricos [...] ser cronista de su tiempo y descubrir la red que liga el destino individual a las subyugantes entidades producidas por la historia [...] No es un "breviario sentimental de un pueblo" tampoco el "fiel espejo" de los bellos paisajes y la bella gente de la comarca vallecaucana, no es un "manual" de costumbres regionales, rico en modismos, cual precioso documental de que hubiera prefigurado los onerosos afanes del lingüista o del científico social actual. ${ }^{27}$

La historia es sencillísima, sin trama, sin acción, el argumento desafía toda descripción, pero ofrece un elemento romántico y fascinador que cautiva al lector. Claro está que ciertos críticos ultramontanos, como el jesuita Pablo Ladrón de Guevara, en su libro Novelistas malos y buenos juzgados en orden de naciones (1910) escribió: "Hay, pues, en la novela María manifestaciones por toda ella francamente cristianas; hay oratorio en aquella casa; sus moradores oran ante la Virgen Santísima y el Crucifijo, principalmente en las tribulaciones, y también, agradecidos, al comer. Sin embargo, aunque sea el espíritu cristiano, lleva mezclado, más o menos, el mundano. Tal cual vez el voluptuoso, y más aún el sensual". ${ }^{28}$

Pero, olvidándonos de tan salido concepto, la base estética de María es la nostalgia, la de los amores de la adolescencia, que de por sí son nostálgicos. Esta nostalgia, según Gustavo Mejía, en el prólogo a la edición de la Editorial Ayacucho, "no es otra cosa que la transposición literaria de la nostalgia del sector de clase latifundista-esclavista, que por 1850 en Colombia sufre un intenso proceso de decadencia, proceso que la familia Isaacs, y muy especialmente Jorge, vivió con especial intensidad". ${ }^{29}$ La nostalgia hace que se describan dos romances centrales: el de María y Efraín, en el que el núcleo humano es la familia de clase latifundista y esclavista de este último, y cuya historia de amor se frustra, y el romance de Tránsito y Braulio, cuyo núcleo humano lo constituye la familia de un pequeño propietario, José, colonizador antioqueño, amigo de la cacería de osos y venados, con quien Efraín caza un tigre y en cuyas comidas el maíz campeaba por todas partes. El ámbito familiar de José es totalmente diferente al mundo de Efraín. El amor entre Tránsito, hija del colono, y Braulio, sobrino del mismo, sí prospera, unión de la que son padrinos Efraín y María. Además

27 Zuñiga, Javier, “María en la literatura nacional”, en: Historia del Gran Cauca. Historia Regional del Suroccidente Colombiano. Fascículo \# 16. Cali: Universidad del Valle-Occidente, enero 29 de 1995, p. 305.

28 Ladrón de Guevara, Pablo, Novelistas malos y buenos juzgados en orden de naciones, citado por Martínez, Op. Cit., p. 174.

29 Mejía, Gustavo. Prólogo a la edición de la Editorial Ayacucho. 
de estos romances centrales, se narran en la novela cuatro secundarios: Nay y Sinar; Carlos, compańero y amigo de Efraín, y María (que por obvias razones fracasa); Emigdio, al igual que Carlos compañero y amigo de Efraín, con Zoila, una ñapanguita de raza mestiza, cuarterona; Tiburcio y Salomé. Acerca de este conjunto de relaciones, y sobre todo de sus protagonistas, el mencionado jesuita Ladrón de Guevara consideró que "algunas descripciones de mujeres, aunque no son deshonestas, tampoco mueven a la castidad, y pueden inquietar, si bien ni lo menos honesto llega a describirlo sino con frase más genérica". ${ }^{30}$

Para los antropólogos ha sido tradicionalmente atrayente la nostálgica, melancólica y triste historia del amor frustrado entre Nay y Sinar, al igual que el romance entre los mulatos Salomé y Tiburcio, quizás por el componente étnico de ambos y por la información etnográfica allí consignada, aunque, en general, toda la novela esta llena de provincianismos, modismos y gentilicios perfectamente explicados en citas de pie de página y al final del libro en un vocabulario. Igualmente abundan las descripciones de diferentes ambientes sociales y culturales del Valle del Cauca rural: comidas, costumbres, vestimentas y trabajos (como los de la boga en el río Dagua). Se debe subrayar también que, con frecuencia, afloran las contradicciones entre lo rural y lo urbano:

[...] los bogotanos les tienen miedo al sol y a los toros bravos; por eso los muchachos se echan a perder en los colegios de allá. No me dejará mentir ese niño bonito (Carlos, el amigo de Efraín) hijo de don Chomo; a las siete de la mañana lo he encontrado de camino aforrado con un pañuelo, de modo que no se le veía sino un ojo, ¡y con paraguas!. ${ }^{31}$

Siempre aparecen las grandes diferencias socio-raciales que aún, para la segunda mitad del siglo XIX, perduraban en la sociedad neogranadina. Es así como, con ocasión del matrimonio de Braulio y Tránsito, Isaacs escribió el siguiente pasaje:

- ¿̇rá a pie Tránsito al pueblo?

- EEh!, exclamó José

- ¿Pues cómo?, preguntó ella admirada

-A caballo, ¿№ están ahí los míos?

- Si a mí me gusta más andar a pie, y a Lucía no es sólo eso, sino que le tiene miedo a las bestias -iPero porqué? preguntó Emma

-Si en la provincia solamente los blancos andan a caballo, ¿No es así padre?

-Sí, y los que no son cuando ya están viejos 
-¿Quién te ha dicho que no eres blanca? Pregunte a Tránsito; y blanca como pocas.

La muchacha se puso colorada como una guinda, al responderme -Las que yo digo son las gentes ricas, las señoras. ${ }^{32}$

O cuando la mulata Salomé le cuenta a Efraín sobre los celos de Tiburcio:

No lo piense, menos tibante había de ser. Porque le han dicho que es hijo de caballero, ya nadie le da al tobillo en lo fachendoso, y se figura que no hay más que él [...] ¡Caramba!, como si yo fuera alguna negra bozal o alguna manumisa como él. Ahora está metido donde las provincianas, y todo por hacerme patear, porque mucho que lo conozco; bien que me alegraría de que ñor José lo echara a la porra. ${ }^{33}$

Ahora bien, Nay o Feliciana era la aya negra de Efraín y María, que posiblemente había sido lo mismo para Isaacs. Su historia es la más larga luego del romance principal, ya que ocupa 20 páginas de las 250 que tiene la novela, 5 capítulos de los 65 que en total posee el libro, y abarca desde que Nay era una princesa Achanti en África hasta su muerte en el Valle del Cauca. Nay se enamoró de su esclavo Sinar, hijo cautivo del caudillo Orsué de la etnia Achimis, y lo hizo su amante secreto. El padre de Nay, Magmahu, fue derrotado en la guerra que los Achantis emprendieron contra los ingleses y al término de la misma decidió trasladarse a Gambia, no sin antes aplacar "la cólera del Tando, ensañado contra mí por mi amor a la gloria, y que le sacrifiquemos lo más granado de nuestros esclavos; Sinar entre ellos el primero". ${ }^{34}$ Ante esto Nay se desmayó, su padre se enteró del secreto y de paso supo que Sinar era hijo de Orsué a quien él había dado muerte, luego de una melodramática escena en que el herido padre amenaza de muerte a Sinar y Nay interviene en su defensa. Magmahú aceptó los hechos y decidió, junto con su hija y su yerno, desplazarse a Cumasia, el país de los Kombu-Manez en las riberas del Gambia, donde los migrantes fueron aceptados. Allí se dedicaron a ayudar a sus benefactores en la cruel guerra que desde tiempo inmemorial enfrentaban con sus vecinos los Cambes.

Al país de los Kombu-Manez llegó un viejo misionero francés que conocía la lengua de los Achimis y entró en buenos tratos con Sinar, quien estaba en vísperas de casarse con Nay por los ritos Kombu-Manez. El misionero convirtió a Nay y a Sinar al cristianismo y los bautizó a orillas del Gambia. Precisamente la noche anterior al casorio, el poblado donde residían fue atacado por los Cambes, 
acción en la que resultó muerto Magmahu, mientras que Nay y Sinar fueron hechos prisioneros y convertidos en esclavos. Nay, que estaba embarazada, fue vendida a tratantes, separada de su enamorado y enviada a América. Una vez superada la tristeza de la pérdida de su padre y de la separación forzosa de Sinar, y luego de salvarse de una epidemia en el barco negrero, el bergantín en que era cautiva Nay llegó al puerto negrero de La Habana. Nay no fue desembarcada en Cuba, continuó viaje hacia la Nueva Granada, donde fue entregada clandestina e ilegalmente después de 1821, cuando ya era prohibida la importación de esclavos, a un comerciante y agricultor irlandés, William Sardick, quien residía en el Golfo de Urabá, no lejos de Turbo, con su esposa, la mestiza cartagenera Gabriela. Junto a la pareja, Nay tuvo a su hijo, Juan Angel, quien fue bautizado por el rito católico a los pocos días de nacer. Al hogar de Sardick llegó el padre de Efraín, quien traía a María, la hija de su primo Salomón, de sólo tres años de edad y quien había perdido recientemente a su madre, tras lo cual había sido entregada por Salomón a su primo para que éste la criara. Rápidamente, Nay y su hijo se hicieron al afecto de la niña huérfana y el padre de Efraín se enteró que Nay había entrado a Nueva Granada en fecha en que por ley ya era libre. Ante la inminente venta de la negra y de su hijo a un comerciante neoyorquino, que la quería llevar a su ciudad de origen, el padre de Efraín compró a la esclava y le dio la libertad, y esta en señal de gratitud decidió internarse con él hacia el Cauca donde vivían su esposa y sus hijos.

Como se ha esbozado, en buena medida, María es una novela autobiográfica. Narra con nostalgia muchos pasajes del "pasado" boyante de los Isaacs y, aunque no profundiza mucho, menciona el colegio del Espíritu Santo "establecido en Bogotá hacía pocos años, y famoso en toda la república por aquel tiempo". ${ }^{35}$ Describe las haciendas del Valle y los supuestos avances allí alcanzados: "En mi ausencia, mi padre había mejorado sus propiedades notablemente, una costosa y bella fábrica de azúcar, muchas fanegadas de caña para abastecerla, extensas dehesas con ganado vacuno y caballar, buenos cebaderos y una lujosa casa de habitación, constituían lo más notable de sus haciendas de tierra caliente". ${ }^{36}$ Con motivo de la llegada de María (Ester) al seno de la familia, Isaacs aprovecha la coyuntura para narrar algunos detalles sobre su padre, su familia en Jamaica, etc. Se describe a sí mismo como un "teórico" de las siembras, y cuenta que en las clases que dictaba a su hermana Emma y a María les hacía leer trozos del Genio del cristianismo y de Atala de Chateaubriand y que al regresar al Cauca había llevado una abundante biblioteca entre la que se destacaban La Biblia, El Quijote, libros de Shakespeare y Calderón, La conquista de México de Hernán 
Cortes, La democracia en América de Tocqueville, entre otros. También narra que por haber estudiado en Bogotá y tener muchos conocimientos sobre diferentes materias, contabilidad especialmente, ayudaba a su padre a ordenar y poner al día cuentas y demás aspectos administrativos de las haciendas.

Sin lugar a dudas Jorge Enrique sintió por Nay o Feliciana particular cariño, sobre todo por las fantásticas narraciones orales que de ella escuchó y que contribuyeron a enriquecer la mente aventurera del escritor y su acervo de información:

Aquella mujer que iba a morir lejos de su patria; aquella mujer que tan dulce afecto me había tenido desde que fue a nuestra casa; en cuyos brazos se durmió tanta veces María siendo niña. Pero he aquí su historia, que referida por Feliciano con rústico y patético lenguaje, entretuvo algunas veladas de mi infancia [...].

Nińos, María y yo, en los momentos en que Feliciana era más complaciente con nosotros, solíamos acariciarla llamándola Nay, pero pronto notamos que se entristecía si le dábamos ese nombre. Alguna vez que sentada a la cabecera de mi cama, a prima noche, me entretenía con uno de sus fantásticos cuentos, se quedó silenciosa luego que lo hubo terminado, y yo creí notar que lloraba

-Porqué lloras? le pregunté.

-Así que seas hombre, me respondió con su más cariñoso acento, harás viajes y nos llevarás a Juan Angel y a mí; ¿ No es cierto?

-Sí, sí, le contesté entusiasmado; iremos a la tierra de esas princesas lindas de tus historias...me las mostrarás...¿Cómo se llama?

-África, contestó.

Yo me soñé esa noche con palacios de oro y oyendo músicas deliciosas. ${ }^{37}$

Parte de la nostalgia y tristeza que se reflejan en María está en el interés y preocupación de Isaacs por la muerte. Con ocasión de la de Nay, por ejemplo, hizo una completa relación de los últimos momentos de la negra Achanti, como el velorio, la parte cristiana y los rezos, y luego de los rituales africanos, los cantos e himnos, entre los que trascribió cuatro versos que conservó en su memoria:

En oscuro calabozo, cuya reja al sol ocultan negros y altos murallones que las prisiones circundan.

En que sólo las cadenas que arrastro, el silencio turban de esta soledad eterna donde ni el viento se escucha... 
Muero sin ver tus montańas,

¡oh patria!, donde mi cuna

Se meció bajo los bosques...

Que no cubrirán mi tumba. ${ }^{38}$

Así mismo, reconstruyó, de labios de Emma, los últimos días de María, su agonía y su muerte: "Estaba como dormida, pero dormida para siempre...jMuerta sin que mis labios hubieren aspirado su postrer aliento, sin que mis oídos hubiesen escuchado su último adiós, sin que alguna de tantas lágrimas vertidas por mí después en su sepulcro, hubiese caído sobre su frente!". ${ }^{39}$ No se extendió mayor cosa en el velorio, pero narró uno de los momentos de mayor ritual cuando Emma, la hermana de Efraín, a las tres de la madrugada, cortó las trenzas de María como legado al amante ausente: "Creí - decíame Emma - que al cortar la primera trenza iba a mirarme tan dulcemente como solía si, reclinada la cabeza en mi falda, le peinaba yo los cabellos. Púselas al pie de la imagen de la Virgen, y por última vez le besé las mejillas. Cuando desperté dos horas después, ya no estaba allí”. ${ }^{40}$

Pero, así como la muerte ocupa algunas de las páginas de María, el baile tiene también un puesto importante en las descripciones de Isaacs. El primer baile que narra es el del matrimonio de Bruno y Remigia, esclavos de las haciendas del Valle:

No habían sino dos flautas de cańa, un tambor improvisado, dos alfandoques y pandereta, pero las finas voces de los negritos entonaban los bambucos con maestría tal, había en sus cantos tan sentida combinación de melancólicos, alegres y ligeros acordes, los versos que cantaban eran tan tiernamente sencillos, que el más culto diletante hubiera escuchado con éxtasis aquella música semisalvaje. ${ }^{41}$

A semejanza de los buenos escritores judíos, Isaacs, en María, tiene un animal que es presagio de malas situaciones: un cuervo (el ave negra) que con su peculiar graznido aparece por primera vez cuando María sufre su primer ataque de epilepsia. Aparece por segunda vez cuando Efraín y su padre, en una de las haciendas de abajo, reciben una carta sobre la evidente quiebra del padre; simultáneamente, en El Paraíso, aparece el ave en el cuarto de Efraín y es descubierto por María, el mismo día del matrimonio de Braulio y Tránsito. Un

38 Ibíd., p. 172.

39 Ibíd., p. 243.

40 Ibíd., p. 244.

41 Ibíd., p. 21. 
día después del regreso de padre e hijo, el padre cayó en cama y durante tres días se debatió entre la vida y la muerte, con frecuentes delirios relacionados con la quiebra. La tercera ocasión en que aparece el siniestro cuervo es cuando Efraín le da a María, informalmente, una argolla de compromiso. La última aparición del ave negra sucede al fin de la novela, cuando ya ha fallecido María sin haber podido volver a ver a Efraín, quien ha viajado a Inglaterra y retorna presuroso un año después de su partida para ya no encontrarla:

Había yo montado y Braulio estrechaba en sus manos una de las mías, cuando el revuelo de un ave que al pasar sobre nuestras cabezas dio un graznido siniestro y conocido para mí, interrumpí nuestra despedida, la ví volar hacia la cruz de hierro, y posada ya en uno de sus brazos, aleteó repitiendo su espantoso canto.

Estremecido, partí a galope por en medio de la pampa solitaria, cuyo vasto horizonte ennegrecía la noche. ${ }^{42}$

Pese a que María le abrió muchas puertas e Isaacs se convirtió en uno de los hombres más admirados y solicitados de la capital y en uno de los miembros más prometedores del partido conservador, con los años éste se desilusionó de haber escrito la novela. En 1878 escribiría: "Ese libro en boca de los que quieren dañarme! ¿Qué es eso? Si fue un pecado escribirlo, ¿así como ellos lo quieren debo purgarlo? Luciano, ¿por qué nos regocijábamos en un tiempo, por amor al país en donde usted y yo nacimos, viendo el buen éxito que obtenía ese libro?”.43 Se subraya que asumió una posición similar cuando El Mosaico publicó su volumen de poesías: "Nos consta que Isaacs no hacia gran caso de esa colección, y aun hubiera querido que la edición desapareciera completamente". ${ }^{44}$

\section{De conservador moderado a liberal radical}

Por la época en que se publicó María, Isaacs estaba residenciado en Bogotá, pues el conservatismo del Cauca lo eligió, en 1866, como diputado al Congreso Nacional y simultáneamente tenía un almacén en el que vendía diversas mercancías importadas. Además, junto con Sergio Arboleda, su antiguo amigo y coterráneo, fundó y dirigió, en 1867 el semanario La República, de tendencia conservadora moderada, que apoyó la candidatura del antioqueño Pedro Justo Berrío (1827-1857) para la presidencia de los Estados Unidos de Colombia.

42 Ibíd., p. 250.

43 Citado por José Eduardo Rueda Enciso en: Jorge Isaacs (1837-1895). Grandes Biografías de Colombia. Barcelona: Océano Grupo Editorial, 1996.

44 Poesías de Jorge Isaacs. Noticia Biográfica y Literaria, en: Roa, Jorge (ed.), Biblioteca Popular. Colección de grandes escritores nacionales y extranjeros. Tomo X. Bogotá: Librería Nueva, 1895, p. 4. 
También colaboró en el periódico La Fé, que dirigía Vergara y Vergara. Todo ello le sirvió para ser elegido representante por el Tolima al Congreso de 1868 y 1869, cargo que ya había ocupado en 1866. Sin embargo, para entonces ya era miembro de la masonería, pues en 1864 aparece como miembro activo de tercer grado de la Logia Estrella del Tequendama número 11, la de mayor tradición en Bogotá. Alcanzó el grado 33 y ayudó a crear la logia Aurora del Cauca con sede en Cali, de la que fueron miembros los generales Mosquera y Pedro Alcántara Herrán (1800-1872) y su primo hermano César Conto. Así mismo, mostraba serias inclinaciones por el liberalismo radical, de lo cual fue acusado en el Congreso por sus copartidarios, a lo que respondió: "Sí, he pasado de las tinieblas a la luz". Sostuvo entonces serios enfrentamientos con la facción más ultramontana del conservadurismo: "Se me había formado republicano y resulté ser soldado insurgente en las filas del partido conservador". Finalmente se convirtió al radicalismo a fines de 1869, lo que nunca le perdonaron sus antiguos correligionarios y sobre todo sus paisanos, entre quienes las ideas conservadoras tenían un gran arraigo. Con frecuencia sus coterráneos caleños se burlaban de él y le inventaban chismes sobre su vida y su cúmulo de fracasos. Sus copartidarios liberales lo llamaban "el león herido del Valle".

En 1869 y 1870 ocupó el cargo de secretario general de la Cámara de Representantes. Criticó con vehemencia el conservatismo ultramontano, defendió la separación del Estado y la Iglesia y, en general, la organización de la nación en torno a un Estado federal; fue uno de los principales promotores de la educación laica y gratuita. En calidad de secretario de la Cámara e imbuido de un espíritu latinoamericano firmó la declaración en que se proclamaba a todos los paraguayos como colombianos, debido a la guerra de la Triple Alianza, que el Paraguay sostenía contra Brasil, Argentina y Uruguay. Los paraguayos perdieron en esa guerra buena parte de su territorio pero siempre recordaron, con gratitud, el gesto de los radicales colombianos y muy especialmente de Isaacs.

En septiembre de 1870 viajó desde Buenaventura con rumbo a Chile, en donde había sido nombrado cónsul. Hizo una escala en Lima, ciudad en la que se hizo amigo del escritor Ricardo Palma y con quien confirmó que los problemas latinoamericanos eran similares y comprendió el ideal bolivariano de una unión de los Estados latinoamericanos. Dos años largos permaneció en tierras australes, los que aprovechó para ampliar su visión del continente y ganar conciencia de que si los países latinoamericanos no se unían en un solo bloque, terminarían solos y aislados del resto del mundo. Su gestión diplomática la orientó a mejorar la opinión que los chilenos tenían de Colombia y a incrementar las relaciones comerciales entre ambos países. Según parece, con frecuencia comentó, respecto al alto grado de cultura política de los chilenos, 
que "mientras en Chile los problemas se resuelven por la vía diplomática, en Colombia seguimos matándonos entre nosotros". ${ }^{45}$ Conoció y se entusiasmó con la obra pedagógica de Andrés Bello, autor del que ya conocía Gramática de la lengua española por intermedio de Vergara y Vergara. Igualmente, se interesó por lo que en Argentina realizaba Domingo Faustino Sarmiento: la educación popular, el caudillismo, los conflictos y armonías de las razas americanas y muy especialmente por el planteamiento de este autor en Civilización o barbarie, lo cual le sirvió para reforzar sus planteamientos federalistas: "Si en Colombia no luchamos por nuestras regiones, crearemos un gobierno centralista, a espaldas del país (...). Si no paramos a tiempo las pugnas por el poder y las guerras que nos desangran diariamente, terminaremos construyendo el país de la barbarie". ${ }^{46}$ Colaboró asimismo en los periódicos El Mercurio y Sud América y en las revistas Santiago y Chilena.

En 1873 volvió al Cauca con la ilusión de crear una gran empresa agrícola con la que quería redimir a su familia de la estreches en que había vivido; consiguió un socio chileno, Ricardo Miguel Infante, miembro de una de las familias más prestantes, y con él compró la hacienda Guayabonegro, en las inmediaciones de Candelaria, a orillas del río Fraile. Confiado en la inminente construcción del Ferrocarril del Pacífico, empresa para la que el gobierno de Manuel Murillo Toro había contratado los servicios del ingeniero cubano Francisco Javier Cisneros (1836-1898), Isaacs tenía planeado consolidar una despensa agrícola cuyos productos debían ser exportados o vendidos en el interior aprovechando el río Cauca. El negocio era audaz y los recursos muy limitados, por lo que pronto se endeudaron con obligaciones muy altas. Infante se retiró como socio capitalista e Isaacs luchó hasta donde pudo, pero al cabo de dos ańos tuvo que declararse en quiebra. Este nuevo fracaso económico fue la comidilla de los periódicos caleños Los Principios y La Unión Liberal y El Cauca de Popayán, a lo que ayudo el siguiente aviso que el escritor difundió:

¡Ricos, buena ocasión! Vendo en términos muy ventajosos para el comprador la hacienda de Guayabonegro. En veinte meses de incesante trabajo, le he hecho a esta hacienda que recibí arruinada, valiosas y muy productivas mejoras en sus edificios, cercas, aguas, cañales y fábricas. En cambio de pagar todo lo que debo renuncio gustoso a las utilidades cuantiosas que podría reportarme el poseer estas fincas por algún tiempo más.

Firmado, Jorge Isaacs. ${ }^{47}$ 
La opinión pública caleña y caucana, muy especialmente la conservadora, que no le perdonó su conversión al liberalismo radical, se encarneció con Isaacs y sacó hojas sueltas como la siguiente:

$\begin{array}{ll}\text { Corteza de Guayabonegro } & 4 \text { onzas } \\ \text { Flores de ilusión pecuniaria } & 1 \text { onza } \\ \text { Conserva añeja de motilones } & 2 \text { dracmas } \\ \text { Extracto alcohólico de vanidad } & 1 \text { onza } \\ \text { Agua de El Fraile } & 2 \text { litros }\end{array}$

Hágase hervir al baño de maría, déjese reposar y fíltrese. ${ }^{48}$

Publicó entonces el opúsculo, en la imprenta de Hurtado en Cali, "A mis amigos y a los negociantes del Cauca", en el que explicó su quiebra y donde escribió: "Ni hogar ni tumba podré tener en el país en que naci". En 1878 la hacienda de "Guayabonegro" fue vendida en subasta pública. Fue esta su segunda quiebra económica y, para solucionarla, aceptó en Palmira en 1874 un cargo en la educación pública primaria del Estado Soberano del Cauca, actividad que, además de ser un empeño del radicalismo, la consideró como "decisiva para el desarrollo del país; sin ella no es posible ejercer la libertad; el analfabetismo y la ignorancia, impide la formación del ciudadano, la realización de la democracia, del progreso y de la paz", ideas que habían despertado su atención desde su viaje a Chile y Argentina. ${ }^{49}$ Copió el modelo que en Argentina había impuesto Domingo Faustino Sarmiento, por lo que, desde un comienzo, propuso la creación de escuelas rurales diurnas y nocturnas, lo que estaba en concordancia con los ideales del radicalismo que había diseñado una política educativa que consagró la educación laica, pública y obligatoria a nivel elemental. El laicismo estaba relacionado con la libertad de conciencia. Esto significó que las escuelas oficiales no imponían ningún credo y que la enseñanza religiosa no era obligatoria, sino opcional; según la voluntad de los padres, los alumnos podrían recibirla de sus párrocos o ministros. El hecho de ser pública significó que era gratuita. La obligatoriedad quería decir que el padre podía educar a su hijo de la manera que lo juzgara conveniente, pero no podía negarle la educación.

El momento en que Isaacs se interesó y empezó a trabajar por la instrucción pública es particularmente importante, pues en noviembre de 1870 se había expedido el Decreto Federal Orgánico de la Enseńanza Primaria, el cual impuso en todo el país la instrucción obligatoria y estableció que cada departamento debía contar con una escuela normal. Isaacs fue uno de los grandes impulsores

48 Citado por Martínez. Op. Cit., p. 102. Los motilones eran los conservadores, a los que Isaacs llamaba así por su naturaleza ultramontana.

49 Buena parte de sus reflexiones sobre el papel de la instrucción pública en esas repúblicas del Sur se encuentran en el articulo "La Confederación Argentina". 
de la reforma en el Estado Soberano del Cauca, pues en 1875 su primo, César Conto, ${ }^{50}$ asumió a nombre del radicalismo la presidencia de este estado por los dos años que constitucionalmente le correspondían, y llamó a Jorge, que ejercía por ese entonces la inspección escolar de la provincia de Cali, para que se hiciera cargo de la Superintendencia de Instrucción Pública del Estado, que era asimilable a ser secretario de instrucción pública. Antes del nombramiento, ambos parientes habían hecho circular la hoja de combate político "Los Motilones", y en Popayán habían editado el periódico doctrinario El Programa Liberal, donde Isaacs sostuvo una enconada polémica contra los conservadores clericales y el periódico tradicionalista Los Principios de Cali.

Como secretario de educación del Estado Soberano del Cauca, Isaacs impulsó las bases para una nueva educación pública: educación primaria, laica y gratuita para todos los habitantes del Estado; separación de la Iglesia y el Estado y muy especialmente la no intromisión de la primera en el sistema educativo estatal. Fortaleció las Escuelas Normales que el decreto de 1870 había instituido, creó las primeras escuelas nocturnas para artesanos y obreros que con el tiempo se convirtieron en escuelas de artes y oficios y planteó la necesaria articulación entre la educación secundaria y el régimen de la Universidad Nacional fundada en 1867. En fin, firmó importantes decretos sobre la instrucción pública, pues era un convencido de que esta era el único medio para modernizar al Cauca y a la nación. Además de Secretario de Educación y editor de prensa -dirigió el periódico El Escolar, desde donde defendió el derecho de los indígenas y los negros a la tierra e impulsó la educación laica en contra de los curas y de los conservadores- Isaacs fue profesor de la Escuela Normal de Popayán. Era un convencido de que la escuela tenía como fin formar al ciudadano, redimir a los indígenas y a los afrodescendientes para el porvenir de la Unión y de que sin instrucción no había desarrollo posible. En el caso de los indígenas, Isaacs no sólo vio la necesidad que ellos tenían de la instrucción pública, también abrogó por sus derechos y, en la medida de lo posible, defendió sus intereses territoriales. En el caso de los negros protegió sus derechos, pues él, mejor que nadie, sabía que la sociedad, economía y cultura del Cauca tenían mucho aporte de la etnia negra.

Sin embargo, Isaacs tuvo que suspender sus funciones de superintendente de instrucción pública y la publicación del Programa Liberal-desde donde Conto impidió su caída como Presidente del Estado Soberano del Cauca-a consecuencia de la guerra civil de 1876, que se inició por el descontento conservador por el

50 César Conto era primo hermano de Isaacs, pues doña Manuela era hermana de Juanita Ferrer, la madre de Conto, quien había tenido un romance, con consecuencias, con un negro chocoano de nombre Joaquín Conto. A consecuencia del nacimiento del niño mulato, la familia Ferrer Scarpeta le volteó la espalda a dońa Juanita, por lo que Contó e Isaacs se criaron separados y sólo se conocieron cuando eran adultos. 
mencionado "Decreto de Instrucción Pública", pues en concepto de estos el gobierno de la Unión se había negado a dar enseñanza religiosa en las escuelas, con el pretexto de una supuesta libertad religiosa y la necesidad de darle curso a la educación laica. La guerra de 1876 en el Cauca fue particularmente álgida, ya que tomó un carácter político-religioso gracias a la agitación que ejercieron los obispos de Popayán, Carlos Bermúdez, y de Pasto, Manuel Canuto Restrepo. El Estado estaba polarizado y las fuerzas militares conservadoras de Antioquia y Tolima invadieron el Valle del Cauca. Este movimiento era esperado y para él se prepararon las fuerzas regulares del Estado. Isaacs estaba precisamente en el norte en esos menesteres e, inmediatamente se dio la invasión, se desplazó a Bogotá y le avisó la novedad al presidente Aquileo Parra. Una vez cumplida esa misión informativa, volvió el 5 de agosto al Cauca donde se puso a las ordenes del coronel Vinagre Neira (comandante del batallón Zapadores), César Conto y Julián Trujillo Largacha (1828-1883). Posteriormente hizo parte del ejército del general Eliseo Payán (1825-1895) durante la campaña que, por la banda occidental del Cauca, permitió la recuperación de Popayán el 26 de abril de 1877. Peleó en la batalla de Los Chancos, del 31 de agosto de 1876, cerca de Tulúa, en la que alcanzó el rango de sargento mayor y jefe del Estado mayor de la Tercera División del Ejército del Sur. Según Juan de Dios "El Indio" Uribe, en esa batalla "Isaacs reemplazó el día antes a Vinagre Neira y a la cabeza del Zapadores, como su primo hermano César Conto, estuvo donde la muerte daba sus mejores golpes". ${ }^{51}$ La guerra civil de 1876 dejó resultados desastrosos pues, por ejemplo, al culminar la batalla de Los Changos, buena parte de los pueblos entre San Pedro y el Tambo quedaron destruidos. Las escuelas públicas, a excepción de la José María Cabal de Buga, la Pedro Antonio Torres de Palmira y la Joaquín Caicedo de Cali, fueron arrasadas.

Una vez terminada la guerra, Isaacs reasumió su cargo de superintendente de instrucción pública y en calidad de tal visitó todos los municipios del Estado Soberano del Cauca, que era el más grande de los nueve Estados Soberanos que conformaban los Estados Unidos de Colombia. Al terminar el período de César Conto en 1877 -que se había caracterizado por un sectarismo exagerado, pues inició una campańa de persecución contra el clero, los conservadores y los liberales independientes con el fin de imponer la candidatura oficial de Aquileo Parra (1825-1900) para el periodo 1876-1878- Isaacs entró a colaborar en el gobierno de don Modesto Garcés, que había sido uno de los secretarios de Conto, y por algún tiempo asumió simultáneamente la Secretaría de Hacienda. Su nombramiento y gestión fueron atacados por el general Mosquera, quien lo consideraba sólo como "un escritor de novelas, sin juicio y circunspección". Ante 
tal presión renunció y asumió su curul en la Cámara, cuerpo en el que permaneció por espacio de tres años y que presidió en 1879. Prometió entonces nunca más volver al Cauca y particularmente a Cali. Según María Teresa Cristina, la crítica literaria y conocedora de la vida y milagros de Isaacs, este "mantuvo siempre con el Cauca una contradictoria relación". En esta nueva etapa como congresista, luchó contra los vientos de centralización que ya se veían venir y se opuso férreamente al clero que llamaba a la guerra a través de las sociedades católicas.

Durante esa nueva incursión en el parlamento, Isaacs se opuso de manera radical a las presiones de la Iglesia sobre el presidente Julián Trujillo, su paisano y copartidario, que había aceptado y propuesto que el Congreso le devolviera las rentas fiscales al clero, les otorgara un indulto a los sacerdotes que habían tomado parte en la guerra y admitiese el regreso de los curas desterrados. Se convirtió, en contra de la corriente, en el gran defensor de la causa liberal. A mediados de 1879 se produjo el incidente conocido como la "lapidación del Congreso" y el presidente Julián Trujillo clausuró la corporación. Isaacs se negó a asistir a las sesiones extraordinarias y aceptó el cargo de secretario del presidente del Estado Soberano de Antioquia, que le ofreció su amigo y coterráneo el general Tomás Rengifo. En Medellín, ejerció también como redactor de La Nueva Era, periódico del régimen y encarnizado defensor del federalismo, desde el cual Isaacs atacó a los nuñistas y a los conservadores.

En enero de 1880 el general Rengifo se retiró, en uso de licencia, de la Presidencia del Estado y lo sustituyó Pedro Restrepo Uribe. Isaacs encabezó entonces una rebelión, tomó Medellín y se proclamó jefe civil y militar de Antioquia, creyendo tener el apoyo del partido y del gobierno central. Debido a las necesidades de la guerra, hubo de decretar empréstitos forzosos, con amenaza de cárcel, contra sus enemigos, que eran sus propios copartidarios, medidas que le crearon odios y enemistades. Además, la fracción derrocada continuó la lucha y el presidente de los Estados Unidos de Colombia, Julián Trujillo, decidió enviar la Guardia Colombiana, que era el ejército federal, a favor de los partidarios de Restrepo Uribe. Isaacs se vio precisado a firmar un pacto de paz el 6 de marzo de 1880, en el campamento de Rancho Largo, cerca de Salamina. A finales de ese mes la Cámara le revocó arbitrariamente su credencial con el argumento de haberse sublevado en armas contra el gobierno nacional y haber incitado a la guerra al Estado Soberano de Antioquia. Esto marcó el fin de la carrera política de Isaacs. Como producto de esa experiencia escribió una serie de panfletos que aparecieron en el periódico La Nueva Era y que se convirtieron en el polémico libro La revolución radical en Antioquia, editado ese mismo año de 1880 en la imprenta de su antiguo editor José Benito Gaitán. Durante su permanencia al mando de las tropas revolucionarias en Antioquia se mostró particularmente 
bárbaro y sanguinario y en las páginas del libro lo ratificó, ya que en él "incitaba al derramamiento de sangre, a la destrucción y a la muerte, llegando incluso a poner como ofrenda su propio cadáver en el campo de batalla". ${ }^{52}$ Luego de este fracaso político y militar, Isaacs no volvió a incursionar en tales campos, en los que no fue propiamente brillante. Sólo en 1885, con ocasión de la guerra de ese año y que dio punto final a los gobiernos radicales, apoyó moralmente al Comité Liberal.

\section{En la Comisión Científica}

Isaacs se autodesterró voluntariamente de su tierra natal, a la que prometió jamás volver, y donde era odiado por los "motilones" de Cali que se burlaban de él y de sus empresas. Se radicó en Ibagué, estaba pobre y sin dinero, por lo que tuvo que vivir en una modesta casa, muy cerca del río Combeima, que le prestó el también escritor Juan de Dios Restrepo "Emiro Kastos" (1825-1884). Allí se suponía que iba a terminar su novela Camilo y, para calmarse de las derrotas sufridas que le produjeron una aguda crisis nerviosa con ribetes depresivos, se dedicó a la jardinería. Viajaba constantemente a Bogotá con el fin de buscar un cargo diplomático en la Argentina, pero no tenía el suficiente apoyo político para conseguirlo. En 1881 publicó el primer canto de "Saulo", poema extenso que quedó inconcluso.

Basado en la lectura de Domingo Faustino Sarmiento, concibió la idea de adelantar un redescubrimiento del país, lo que implicaba caminarlo palmo a palmo en búsqueda de nuevas posibilidades económicas. Obtuvo entonces el nombramiento, por un año, de secretario de la recién creada Comisión Científica Permanente y una asignación anual de 3.000 pesos. Esta comisión estaba a cargo del explorador Angelino Manó, de nacionalidad argelina, y debía continuar las exploraciones iniciadas por Agustín Codazzi (1793-1859) en la Comisión Corográfica entre 1850 y 1859. Entre sus funciones tenía que revisar y redactar los trabajos de los demás miembros de la expedición, y escribir sus propias observaciones sobre costumbres, situación de la educación pública, de la higiene y del acueducto y alcantarillado; algo parecido a lo que en la Comisión Corográfica había cumplido Manuel Ancízar (1812-1882) entre 1850 y 1852 y que dio lugar a la "Peregrinación de Alpha". Estas observaciones se publicarían en los "Anales de Instrucción Pública".

En octubre de 1881 partió Isaacs para el inexplorado Estado del Magdalena. Durante once meses, hasta septiembre de 1882, se dedicó a la exploración de la Sierra Nevada de Santa Marta, la península de la Guajira, las riberas del golfo de 
Urabá y las riberas del río Magdalena. Antes de partir, habló Isaacs con Ancízar, su hermano masón, y en boca de Isaacs: "el ilustre y bondadoso maestro me estimuló para la ejecución de una obra así, verdaderamente superior a mis fuerzas, y las últimas palabras animadoras, de cariño, casi paternales, que oí de sus labios, diéronme muchas veces persistencia de voluntad, fe en el éxito -ilusoria pero necesaria- y ánimo paciente, probado sin conmiseración en tantas ocasiones" ${ }^{53}$ Desde un comienzo las relaciones personales entre los miembros de la Comisión fueron tirantes e Isaacs decidió continuar solo su periplo. De su propia cuenta y riesgo envió informes periódicos al gobierno central respecto de los recursos minerales aprovechables. De esos viajes surgió el libro Estudio sobre las tribus indigenas del Magdalena (1884), que fue severamente criticado por su antiguo amigo y después redomado enemigo Miguel Antonio Caro, quien lo descalificó tratándolo de darwinista y judío, y a su vez defendió y exaltó la abnegada tarea de los misioneros en el mundo entero en pro de la expansión de la fe de Cristo. En fin, el ultramontano combatió las ideas y las actitudes religiosas de su antiguo amigo, negándole todo valor al esfuerzo personal y al trabajo de campo adelantado por Isaacs, lo que es lógico, pues Caro nunca conoció el mar, lo más lejos del perímetro de Bogotá a donde se aventuró fue Sopó, donde poseía la hacienda Casablanca. Nunca supo las dificultades, crisis etc., que enfrenta un investigador en el campo, así como el ingenio y habilidad que debe desplegar para conseguir la información, habida cuenta del trabajo de preparación de la exploración y la ordenación, sistematización y redacción del producto final, llámese este informe o publicación. Todo ello lo plasma Isaacs en su libro:

Investigaciones minuciosas, esfuerzo tenaz: captarse el respeto y cariño de los jefes y sacerdotes, y el de sus allegados, lo primero; recorrer así, ya en compañía de algunos salvajes, las comarcas que habitan y los desiertos donde imperan; en el estudio de los idiomas no perder instante propicio para la adquisición de un dato valioso, de una palabra nueva, de un giro extraño; obtener de los ancianos, mediante dones, benevolencias y astucia paciente, lo que no ha sido fácil conseguir de los jefes y médicos-sacerdotes, en lo relativo a tradiciones y creencias religiosas; conquistar el afecto de las mujeres, comúnmente agreñas y recelosas al principio, con regalos de bujerías y bagatelas, que estiman mucho para adornarse a su modo, y acariciar a los niños, tributando consideración a las ancianas: en fin, días y noches, perdido el recuerdo de número y de fechas, sin otra sociedad que la de gentes bárbaras, sin más techo, ni hogar ni cuidados que los suyos; por horizonte, lo no visto, lo grandioso, lo ignorado...y 
sed insaciable de eso; una impaciencia indócil a las caricias del sueño, y fuerte, sin ligaduras y zozobras, el alma libre. ${ }^{54}$

Para la etnología y la antropología colombiana el tratado escrito por Isaacs tiene un valor importante, pues sus observaciones tienen que ver con la lingüística, la etnografía y la antropología de los indígenas asentados en la Sierra Nevada de Santa Marta, hasta ese momento prácticamente desconocidos o estudiados de manera ligera y sin rigor, por lo que

Recogió directamente de los mamos relatos mitológicos alusivos al origen del mundo y a la procedencia de los hombres, según las propias concepciones de su mentalidad primitiva. Muchos de estos mitos y leyendas están hoy completamente desaparecidos o han sido reformados considerablemente en épocas posteriores. De aquí la importancia de estas historias, que sirven como puntos de referencia para el estudio de la evolución de las formas religiosas a través de los tiempos recientes y para medir e interpretar el proceso de aculturación determinado por el contacto moderno entre las tribus indígenas y otros conjuntos étnicos, tales como los grupos de colonos blancos, mestizos y negros. 55

El libro tiene una presentación poco convencional, pues arranca con la presentación de serias y completas recopilaciones de las lenguas businka y guajiro: vocabularios acompañados de alfabeto, sonidos elementales, signos ortográficos (acentuación), pronombres personales y posesivos, adverbios de lugar, cantidad, modo, tiempo, afirmación y negación; expresiones interrogativas, preposiciones, conjunciones, adjetivos, sustantivos, verbos, numerales, nombres propios de varones y mujeres, fraseología. Además, tres muestras de los vocabularios de las lenguas guamaka, chimila y motilón, para lo que tuvo como guía a Rafael Celedón. ${ }^{56}$

El libro continúa, con algún detalle, en consideraciones relativas a la geografía (orografía e hidrología), la historia y la demografía, para lo que refutó las informaciones de los cronistas de Indias, ${ }^{57}$ las geografías de Sergio Arboled ${ }^{58}$ y

54 Isaacs, Jorge, Estudio sobre las tribus indígenas del Magdalena, Bogotá: Biblioteca Popular de Cultura Colombiana, 1951, p. 24.

55 Duque Gómez Luis. Prologo al libro Estudio sobre las tribus indigenas del Magdalena. Bogotá: Biblioteca Popular de Cultura Colombiana, 1951, p. 12.

56 Celedón, Rafael, Gramática, Catecismo y Vocabulario de la lengua Guajira, París, 1878.

57 Muy especialmente Juan de Castellanos, Elegias de Varones Ilustres de Indias, y Lucas Fernández Piedrahita, Historia general de las Conquistas del Nuevo Reino de Granada.

58 Arboleda, Sergio, Rudimentos de Geografía, Cronología e Historia. (1872). 
osé Manuel Royo. ${ }^{59}$ Se basó, aunque lo rectificó, en Felipe Pérez, ${ }^{60}$ y en informes coloniales como el que el 19 de mayo de 1778 rindió Antonio de Narváez y Latorre, Gobernador de la Provincia de Santa Marta, al Virrey don Manuel Antonio Flórez, y en viajeros del siglo XIX (Reclus, Truchon y Striffer ). ${ }^{61}$ Citó a Quijano Otero, ${ }^{62}$ consultó Reales Ordenes, retomó y rectificó los trabajos geográficos del Coronel Joaquín Acosta, la carta geográfica de F. A. A. Simonns, ${ }^{63}$ Ricardo S. Pereira, ${ }^{64}$ Joaquín Esguerra, ${ }^{65}$ del Coronel don Antonio de Alcedo, ${ }^{66}$ y de Tomás Cipriano de Mosquera. ${ }^{67}$

Las rectificaciones y refutaciones las hizo basado en un principio: "La geografía no se inventa", ${ }^{68}$ y en su pretendido "estudio detenido de aquella región" ${ }^{69}$ que durante once meses exploró a conciencia. Es enfático en afirmar que los errores y sobre todo las fantasías consignados en el trabajo de Felipe Pérez (el cual considera como el más serio, y que utilizó como libro de cabecera y de permanente consulta) radican en dos circunstancias: la Comisión Corográfica no exploró el Estado del Magdalena y obviamente tampoco la Sierra Nevada de Santa Marta, lo que implicó que Pérez se basara en las narraciones, consignadas en un informe destinado a promover la colonización de la Sierra Nevada, del ingeniero John May:

En un informe enviado al Comité de tenedores de la deuda colombiana, el seńor Felipe Pérez, tomando a veras las imaginaciones del ingeniero descriptor - lo que le hubiera sucedido a cualquier hombre serio en su lugar- insertó pasajes en aquel informe en su Geografía de los Estados Unidos de Colombia, publicada en 1863. Prohijó también en su Diccionario Geográfico el señor Joaquín

59 Royo, José Manuel, Nueva Geografía Universal, (1882).

60 Pérez, Felipe, Geografía Física yppolitica de los Estados Unidos de Colombia, (1863) y (1883).

61 De Narváez y Latorre, Antonio, Relación e informe de la Provincia de Santamarta y Riohacha por lo que respecta al estado actual de su comercio, labranzas, haciendas y frutos, que manifiesta los pocos que se cogen ahora y los que pueden cultivarse y conviene fomentar, y medios que se consideran oportunos para adelantar estos importantes objetos con beneficio de la Provincia, de sus vecinos, y de todo el Reino. Original en la Biblioteca Nacional de Colombia, en el legajo que lleva por rótulo: Nuevo Reino de Granada-Caracas.

62 Quijano Otero, José María, Historia Patria. (1883).

63 Simmons, F. A. A., South America. Map of Sierra Nevada de Santa Marta. State of Magdalena, United States of Colombia (1881).

64 Pereira, Ricardo S., Les Etats-Unis de Colombia, précis d'histoire et de Géographie Physique, politique et comerciale, París, 1883.

65 Esguerra, Joaquín, Diccionario geográfico de los Estados Unidos de Colombia, (1879).

66 De Alcedo, Antonio, Diccionario Geográfico-Histórico, Madrid: 1788.

67 De Mosquera, Tomás Cipriano, Geografía de los Estados Unidos de Colombia, París, 1866.

68 Isaacs, Jorge, Estudio sobre las tribus indigenas del Magdalena, Bogotá: Biblioteca Popular de Cultura Colombiana, 1951, p. 110.

69 Ibídem, p. 111. 
Esguerra todo aquello que quiso idear el señor May describiendo regiones de la Sierra que no había recorrido. De suerte que en lo que en muchas aulas de geografía del país, se estudia y sabe acerca de las montañas dichas, es muy interesante y bonito, si se quiere, pero casi todo inexacto. ${ }^{70}$

Algo similar a lo hecho con la geografía realizó Isaacs con la etnohistoria y la etnografía. Le prestó particular importancia a la interpretación del arte rupestre, presente en varios sitios del Departamento del Magdalena, en adoratorios recónditos de las montańas. Interpretaciones por demás bastante ingenuas. Sin embargo, es particularmente importante la reproducción, en cuatro láminas, de 94 ideogramas, los de mayor frecuencia.

Ahora bien, la azarosa y a veces frustrante vida que había llevado a cabo Isaacs durante su ciclo vital le había generado muchas incertidumbres e inseguridades, así como una modestia que se refleja en el primer párrafo de la introducción al Estudio: "La que pide este trabajo, que doy a la prensa con justificable timidez, será lectura inútil para los etnógrafos y arqueólogos que le dediquen alguna atención en otros países de América, si él merece tal honra". ${ }^{71}$ Sin embargo, hace un llamado de atención al "estado del arte" de la investigación en ese momento, que puede extenderse a las generaciones actuales: "Los hombres de ciencia juzgarán únicamente por la valía o importancia de los resultados; es lo natural y lógico, es su derecho temible; más los del país sí tendrán en cuenta que sólo ahora está él dando los primeros pasos, vacilantes por lo mismo, en este género de estudios, tan ocasionados a dificultades, hostilidad y peligros en las comarcas salvajes, como amenos en las civilizadas y en la blancura y grato calor del gabinete" ${ }^{72} \mathrm{~A}$ lo largo de las 289 páginas del Estudio sobre las tribus indígenas del Magdalena se muestra el conocimiento que tenía Isaacs de la historia, de los escritores que habían escrito sobre dicha región, de las necesidades investigativas y administrativas, etc.

La obra de los territorios ocupados por tribus salvajes, no sólo pide administradores cultos y filántropos y labor de etnógrafos y arqueólogos; requiere misioneros de aptitudes probadas, de virtudes eximias, de mansedumbre y perseverancia admirables. Suponíamelo así antes de estudiar las tribus del Estado del Magdalena, pero aún vacilaba; después no. Ellas son la sangre rica y sana de aquella región

70 Ibíd., p. 117. Según Isaacs, May no trasmontó la Sierra Nevada, sólo llegó hasta San Sebastián de Rábago, por lo que se equivocó en la altura de la Sierra, y en la altitud en que comenzaban las nieves perpetuas. Por estos y otros datos lo consideró como "mentiroso, pintoresco y fantasioso" (pp. 123 a 129). Obviamente May analizó los sitios más propicios para una eventual colonización de extranjeros.

71 Ibíd., p. 14.

72 Ibíd., pp. 15 y 16 . 
e Colombia, son gérmen valiosísimo y obligado de toda prosperidad allí; y un absurdo y caro sistema de administración, socaliñas fiscales, torpes abusos, vicios que los mercaderes importan y estimulan, las irritan, las embrutecen y las envenenan. ${ }^{73}$

La obra, además de estar excelentemente escrita, tiene un gran componente científico: de trabajo de campo y de gabinete. Existen diferencias entre las descripciones geográficas y etnológicas consignadas en el Estudio y María. Las de la obra literaria son producto de un hombre joven, en el momento de la publicación de María contaba con 30 años y la había iniciado a los 27, sin el bagaje que posteriormente adquirió por sus cargos y viajes. Aunque acertadas, en ellas media el sentimiento del escritor. Las de la obra científica muestran la madurez, Isaacs contaba con 47 años, el conocimiento de una bibliografía, de los avances en materia científica. Sin dejar de mediar el sentimiento, se atraviesa la racionalidad propia del hombre de ciencia.

En la exploración que llevó a cabo, Isaacs descubrió yacimientos carboníferos en los desiertos de Aracataca que lo llevaron a escribir informes sobre las posibilidades de explotación de esas riquezas y que fueron recogidos en el volumen titulado Hulleras de la República de Colombia en la Costa Atlántica (1890). Así llegó a idear otra gran empresa con apoyo norteamericano y francés para explotar esas minas. Celebró entonces, el 19 de agosto de 1886, un contrato con el Ministro de Hacienda, Antonio Roldán, para organizar en 18 meses una compañía con capital suficiente para la explotación, extendiendo el privilegio desde el río San Sebastián o Fundación hasta el Sevilla, y también a las carboneras que la compañía encontrase en el macizo, estribaciones, hoyas y litoral de la Sierra Nevada de Santa Marta, en el territorio de la Guajira y en el golfo de Uraba. De la concesión no derivó provecho alguno y sólo después de muchos años, muerto ya Isaacs, la familia obtuvo un mínimo patrimonio, gracias a la defensa que de esos derechos hizo Rafael Uribe Uribe (1859-1914). Diez años permaneció Isaacs vinculado a la región del Magdalena, con algunas interrupciones suscitadas por las fiebres del implacable paludismo, períodos de recuperación en los cuales cumplió labores docentes como Director de Instrucción Pública del Tolima, cargo que ejerció entre enero de 1883 y mayo de 1884, y desde donde editó el periódico La Escuela de Neiva. Se dedicó a explorar la región meridional de Cundinamarca, donde creyó encontrar el eslabón perdido.

En 1886, Isaacs efectuó una segunda exploración por las tierras del Magdalena y la Guajira, especialmente la región occidental, en un bote que llamó Cáscara de Nuez y cuya narración también apareció en los Anales de Instrucción Pública. A partir de 1887 colaboró para el periódico antioqueño El Espectador, periódico 
político, literario, noticioso e industrial que en ese mismo año, el 22 de marzo, había aparecido con su primer número bajo la dirección del liberal antioqueño don Fidel Cano (1854-1919).

\section{Los últimos ańos}

De regreso al Tolima, en 1888, Jorge Isaacs descubrió en los alrededores de Ibagué diversas minas de oro de filón y de aluvión y otra vez se ilusionó con fundar una gran empresa, pero el paludismo y la realidad se lo impidieron. Los últimos años de su vida fueron melancólicos, a causa de su pobreza y desengaño por la vida. Los vivió con su familia en Ibagué, ciudad en la que sus hijos mayores habían establecido una tienda de comercio. Se dedicó a extraer cera y miel, a reclamar del gobierno el pago de sus trabajos en la Comisión Científica y a tratar de conseguir financiación extranjera para la explotación de las hulleras, circunstancias éstas que le obligaron a viajar constantemente a la ciudad de Bogotá, donde trabó gran amistad con José Asunción Silva y con su familia.

Isaacs había conocido a Ricardo Silva, el padre de José Asunción, en las épocas de la tertulia del Mosaico y posteriormente, cuando ejerció como parlamentario y comerciante, ambos amigos de la tertulia frecuentemente se sentaban a departir. La amistad continuó y se hizo extensiva a José Asunción, y no cesó tras la muerte de Ricardo en 1887. Sabemos, por el libro de Enrique Santos Molano, que en 1886 Jorge Isaacs desmontó en Bogotá, de paso para Ibagué. Silva lo hospedó en Chantilly, la casa de veraneo que la familia Silva tenía en el semicampestre Chapinero, en las cercanías de la iglesia de Lourdes. Isaacs venía cansado de descubrir minas de carbón que nadie le agradecía, y cargado de proyectos de novelas de carácter histórico, algunos de cuyos capítulos leyó a doña Vicente, a Elvira y a José Asunción.

Esos proyectos literarios quedarían enterrados en las minas ruinosas de carbón en las que, hacía tiempo, el poeta del Río Moro había sepultado sus sueños. Lo que sucedió fue que en sus horas libres se documentaba para escribir un libro que creía iba a superar a María: se trataba de una trilogía del Gran Cauca, que debía estar conformada por las novelas Fania, Camilo (o Alma Negra) y Soledad, para lo cual escribía constantemente a sus amigos del Cauca en solicitud de datos y noticias. Necesitaba obtener información sobre la indumentaria de fines del período colonial y principios de la República, sobre modismos y canciones populares, sobre este o aquel detalle de una persona o de un lugar. Le interesaba especialmente el paso del Libertador por el Valle en 1822 y a su regreso de la campaña del Perú en 1827. Que se sepa, alcanzó a escribir seis capítulos de Camilo, la novela que inició luego de la quiebra de Guayabonegro, que giraba en 
torno a la vida del Libertador Simón Bolívar, que había sido amigo de su padre desde cuando el Libertador estuvo en Jamaica en 1816. Nunca pudo llevar la novela a feliz término, dado que

su cabeza no podía concentrarse en un segundo proyecto literario porque el fracaso de Guayabonegro le recordaba la derrota que había tenido su padre cuando los acreedores se quedaron con la hacienda Manuelita. Isaacs era incapaz de darle cuerpo a la imagen literaria de Bolívar en su proyecto titulado Camilo porque en su memoria aún estaba viva la imagen de María. ${ }^{74}$

La compenetración entre Jorge Isaacs y José Asunción Silva llegó a ser fuerte. Para la navidad de 1887, Isaacs pasó la festividad con la familia de Silva. Más adelante, a finales de noviembre de 1889, el bardo vallecaucano volvió a visitar a la familia Silva y les informó que Rollo Orden, uno de los traductores más famosos de los grandes libros en español, acababa de terminar la versión inglesa de María, la cual sería publicada por Harper Brothers de Nueva York en el primer semestre de 1890. El 4 de diciembre los Silva Gómez se llevaron a Isaacs para Chantilly, donde fue agasajado con una opípara comida el 7 de diciembre, la misma noche que se inauguró la luz eléctrica en Bogotá y en la que por poco se incendia toda la ciudad. Isaacs volvió a visitar a sus entrańables amigos a fines de septiembre de 1890. En esa ocasión las fiebres malignas, contraídas cuando trabajó en la construcción del camino a Buenaventura, le produjeron una crisis que lo mantuvieron al borde de la muerte. Elvira Silva lo atendió durante diez días con sus noches, tarea en la que la asistió el doctor Carlos Esquerra y dońa Mercedes Holguín de Uribe. Los esfuerzos de Elvira y de dońa Mercedes lograron sacar adelante al paciente, quien había sido desahuciado por el doctor Esguerra. El 11 de enero de 1891 murió de neumonía Elvira Silva e Isaacs le dedicó una conmovedora elegía en carta enviada a José Asunción el 17 de enero. La amistad entre el romántico y el modernista fue "devota, se limitó por las ausencias del autor de María". De todas maneras Isaacs, junto con Elvira Silva, Helena Miralla Zuleta y Baldomero Sanín Cano, fue de los contados amigos que tuvo Silva.

El 19 de enero de 1891, ocho días después de la muerte de Elvira Silva, el juzgado segundo del circuito de Bogotá decretó el embargo de los bienes inmuebles de Isaacs a favor de José Camacho Roldán y Compañía, quien adelantaba un juicio ejecutivo contra Isaacs. A raíz de esa situación, Isaacs volvió a visitar, el 24 de enero, a sus amigos, pero por razones del duelo familiar se alojó en un hotel capitalino. En ese mismo año de 1891, Isaacs volvió a Bogotá, y el 20 de agosto, junto con Silva, visitó al poeta Rafael Pombo (1833-1912), quien 
se encontraba delicado de salud a consecuencia de una bronquitis. El primero de septiembre, Silva e Isaacs visitaron la tumba de Elvira en el Cementerio Central y al otro día el autor de María partió para Ibagué. En 1893 publicó el extenso poema Tierra de Córdova dedicado a Antioquia, a la raza antioqueña, a las gentes de la "montańa" entre quienes quiso que se le enterrara, según se lo expresó en carta a su amigo Juan Clímaco Arbélaez. El 22 de mayo de 1894 volvió Isaacs a la capital del país acompañado de su hijo Lisímaco, con el fin de recibir un homenaje por su labor industrial. Se alojaron en la casa de José Asunción Silva, quien acababa de ser nombrado como diplomático en Venezuela. Permaneció Isaacs en Bogotá hasta el tres de agosto, se despidió de Silva en la Estación de la Sabana y fue esta la última vez que ambos amigos se vieron en vida.

El proyecto de la trilogía sobre el Gran Cauca sólo quedó en la mente de Isaacs, pues murió el 17 de abril de 1895 en Ibagué, en el más total de los anonimatos. "A Isaacs que es gloria nacional, no se le ha tributado ningún homenaje póstumo. ¿Habremos descendido tanto para no honrarnos a nosotros mismos honrando á nuestros grandes hombres?". ${ }^{75} \mathrm{Su}$ féretro fue construido por el ebanista de Ibagué, don Clímaco Gómez, quien cumplió con el deseo de Isaacs de que el cajón debía contener su cadáver y permitir que este fuera enterrado de pie, de acuerdo con el rito masón. Sus restos mortales fueron trasladados a Medellín en 1905, en donde la gobernación de Antioquia le hizo levantar un mausoleo elaborado por el escultor Marco Tobón Mejía.

\section{Bibliografía}

- Arboleda, Julio, Diccionario biográfico y genealógico del antiguo Departamento del Cauca, Bogotá: Horizontes, 1962.

—Cristina Z., María Teresa, "Isaacs y la Educación”, en: Credencial Historia, abril de 1995 .

-Isaacs, Jorge, María. Caracas: Biblioteca Ayacucho, 1978. Prólogo de Gustavo Mejía.

María, Bogotá: Panamericana, 1997. Prólogo sin firma.

75 Poesías de Jorge Isaacs. Noticia Biográfica y Literaria, en: Roa, Jorge (ed.), Biblioteca Popular. Colección de grandes escritores nacionales y extranjeros. Tomo X. Bogotá: Librería Nueva, 1895, p. 5. 
María: una mirada fotográfica al Valle del Cauca. Introducción de Sylvia Patińo: "Jorge Isaacs el gran retratista del Valle del Cauca". Presentación de María Teresa Cristina. Cali: Panamericana Formas e Impresos, 2002.

Estudio sobre las tribus indigenas del Magdalena. Bogotá: Biblioteca Popular de Cultura Colombiana, 1951. Prólogo de Luís Duque Gómez.

- López Michelsen, Alfonso, "Ensayo sobre la influencia semítica en María", en: Ensayistas colombianos del siglo XIX. Bogotá: Biblioteca Básica Colombiana, No 10, Instituto colombiano de cultura, 1976.

-Morales Gómez, Jorge, "Isaacs, viajero y explorador", En: Credencial Historia, mayo de 1995.

-Rodríguez Morales, Ricardo, "Jorge Isaacs (1837-1895), mucho más que un novelista”, en: Credencial Historia, abril de 1995.

-Rueda Enciso, José Eduardo, “Jorge Isaacs (1837-1895)”, en: Grandes Biografias de Colombia, Barcelona: Océano Grupo Editorial, 1996.

-Santos Molano, Enrique, El Corazón del Poeta, Bogotá: Nuevo Rumbo Editores, 1992.

-Sourdis Nájera, Adelaida, "El registro oculto. Los sefardies del caribe en la formación de la nación colombiana 1813-1886", Tesis de la Maestría en Investigación Social Interdisciplinaria de La Universidad Distrital "Francisco José de Caldas", enero de 2000.

-Valencia Llano, Alonso, "La agitada vida política de Jorge Isaacs”, en: Credencial Historia, abril de 1995.

"El Estado Soberano del Cauca", en: Historia del Gran Cauca. Historia regional del suroccidente colombiano, Cali: OccidenteUniversidad del Cauca, 1994. Fascículo 7, noviembre de 1994.

-Zúñiga, Javier, "María en la literatura nacional", en: Historia del Gran Cauca, Cali: Occidente-Universidad del Valle, 1995. Fascículo 16, Enero 29 de 1995. 